THE AMERICAN JOURNAL OF SOCIAL SCIENCE AND EDUCATION INNOVATIONS

[Volume-II Issue-III][Pages = X-XVIII][Mar 2020]

Website: http://usajournalshub.com/index.php/tajssei ISSN (e): 2689-100X

Impact Factor 2019 (5.366) Impact Factor For Current Year (5.525)

\title{
Independence And Responsibility Of The Executive Branch Of The Republic Of Uzbekistan
}

Article Doi:- https://doi.org/10.37547/tajssei/Volume02Issue03-01

\author{
Rakhim Hakimov, \\ Doctor Of Law, \\ Professor Of The Department Of State Law And Management \\ Tashkent State University Of Law, Uzbekistan
}

\begin{abstract}
This article highlights the effective functioning of the state as a set of bodies performing its various functions, with the interaction of all sectors of the state apparatus, with the adoption of laws regulating social relations and ensuring their accurate and effective implementation, the Cabinet of Ministers of the Republic of Uzbekistan and all executive bodies not only enforcing the laws, ensuring their unconditional implementation, but also increasing the responsibility for all the functions, taking into account the experience of the constitutions of foreign countries, discusses issues of further strengthening the independence of the executive branch and increasing its responsibility, increasing the role of the institution of parliamentary control over the implementation of adopted laws and identifying areas of stable public relations regulated by the parliament in the Constitution of the Republic of Uzbekistan.
\end{abstract}

Keywords: State apparatus, Cabinet of Ministers, Public service, lawmaking, parliament, parliamentary control, departmental documents, democratic reforms, branches of power.

\section{Introduction}

The effective functioning of the state as a set of bodies performing its various functions is closely related to the mutual cooperation of all branches of state power. In addition to the adoption of laws governing public relations, ensuring their clear and effective implementation in practice is one of the pressing issues. 


\title{
[Volume-II Issue-III][Pages = X-XVIII][Mar 2020]
}

\author{
Website: http://usajournalshub.com/index.php/tajssei ISSN (e): 2689-100X
}

Impact Factor 2019 (5.366) Impact Factor For Current Year (5.525)

In our country, the issue of increasing the responsibility of state authorities of the Republic of Uzbekistan has become urgent not only for the enforcement of laws, ensuring their unconditional implementation, but also for the implementation of all the functions of the Cabinet of Ministers and the executive branch of the Republic of Uzbekistan. Therefore, it is not surprising that in the appeal of the President of the Republic of Uzbekistan Sh.Mirziyoyev to the chambers of the Supreme Assembly of Uzbekistan, the executive authorities set the task of fulfilling the tasks assigned to them, clearly defining the scope of their responsibility, among the priority areas for improving the system of state and social construction. ${ }^{1}$

In a modern legal democratic state, the executive branch is not subordinate to other branches of government, but is independent in its activities and has enormous potential. At the same time, the executive branch has the right to control other branches of government. ${ }^{2}$

The scientific literature is based on the fact that the ideas of interdependence of the branches of government are directly aimed at ensuring their independence. In this regard, the focus is on noninterference by the branches of government. Commenting on the fact that state power networks do not interfere with each other's activities, the lawyer Yu. N. Sterilov noted that the principle of separation of state power in the matter means not only the expression of mutual equality of the legislative, executive and judicial power networks of the state power, but also the establishment of relations between them in a healthy competitive environment. ${ }^{3}$

Supporting the idea of mutual equality of networks of public authorities, the organization of relations between them in a healthy competitive environment, legal scholar V. E. Chirkin emphasizes in his work that the main emphasis is on the interaction and communication of the branches of government, especially between the branches of the legislative and executive branches. In his opinion, such cooperation is an important and integral component of the printing press of the separation of state power of the present, along with the idea of "keeping each other in harmony and balance."4

Based on the above, the relationship between the legislative and executive authorities depends not only on each other, but also on the establishment and implementation of effective cooperation between them. At the same time, the organization of the legislative and executive branches of government is manifested in cooperation based on the national interests of the state.

It is important to ensure the interaction of the legislative and Executive branches of state power with the exclusive competence of the chambers of the Supreme Assembly of Uzbekistan, which determines the system and powers of the Executive bodies defined in paragraph 5 of article 78 of the Constitution of the Republic of Uzbekistan. Different approaches in the constitutions of foreign States regarding the

\footnotetext{
1 Address by the President of the Republic of Uzbekistan Shavkat Mirziyoev to the Supreme Assembly // http://pressservice.uz/uz/lists/view/1371

${ }^{2}$ Hamaneva N.Yu. Executive power in Russia. History and modernity, problems and development prospects - New Legal Culture, 2004 - P. 4.

${ }^{3}$ Starilov Yu.N. General Administrative Law Course. T. 1. M .: Norma, 2002.-P. 67.

${ }^{4}$ Chirkin V.E. Fundamentals of comparative state science. M.: Lawyer, 2001 .- P.85.
} 


\title{
THE AMERICAN JOURNAL OF SOCIAL SCIENCE AND EDUCATION INNOVATIONS
}

\section{[Volume-II Issue-III][Pages = X-XVIII][Mar 2020]}

\section{Website: http://usajournalshub.com/index.php/tajssei ISSN (e): 2689-100X}

\author{
Impact Factor 2019 (5.366) Impact Factor For Current Year (5.525)
}

establishment of the system and powers of the Parliament are Executive structures. In particular, article 48 of the Brazilian Constitution provides for parliamentary powers, including the introduction, reorganization and elimination of posts and positions in public authorities, the formation of structures and management bodies, administrative bodies and ministries ${ }^{5}$. Unlike other countries, Article 62 of the Constitution of the People's Republic of China provides for the approval of education provincial cities, Autonomous regions, provinces and special administrative districts and their regimes as authority, similar to the powers of the Parliament of the People's Republic of China. ${ }^{6}$

As already mentioned, article 78 of the Constitution of the Republic of Uzbekistan establishes the joint powers of the Legislative chamber and the Senate of the Supreme Assembly of the Republic of Uzbekistan. Adoption of the Constitution of the Republic of Uzbekistan, making amendments and additions to article 78 of the Constitution as the direct authority of the Supreme Assembly in the field of law-making; Adoption of constitutional laws and laws of the Republic of Uzbekistan, making changes; legislative regulation of customs, currency and credit. In turn, the norm creativity can be found in the constitutional norms of the Cabinet of Ministers of the Republic of Uzbekistan, which are the executive authorities of its activities. Indeed, Article 98 of the Constitution defines the Cabinet of Ministers of the Republic of Uzbekistan within the framework of constitutional norms and in accordance with the current legislation, issuing decisions and orders that are mandatory for execution by all bodies, enterprises, institutions, organizations, officials and citizens of the Republic of Uzbekistan in the whole territory of the Republic of Uzbekistan.

It should be noted that the Supreme Assembly of the Republic of Uzbekistan and the Cabinet of Ministers of the Republic of Uzbekistan are engaged in lawmaking. This, in turn, leads the Government of the Republic of Uzbekistan to directly regulate the most important areas of public life in the practice of law enforcement and lawmaking.

At the same time, the laws developed by the Cabinet of Ministers are also of a circular significance, and the law does not establish mechanisms for the implementation of laws. For example, traffic rules play a special role in public life, in particular in the regulation of pedestrians and vehicles that are participants of the road. In most foreign laws, traffic rules are directly regulated by law. In our country, despite the fact that traffic rules are still an important area of public life, it is still being approved by the Cabinet of Ministers. In particular, by the Resolution of the Cabinet of Ministers of the Republic of Uzbekistan №472 dated December 11, 2000, the "Traffic Regulations" were approved and the new edition was abolished by the Decree of the Cabinet of Ministers №370 dated December 24, 2015. It is noteworthy that the Code of Administrative Responsibility of the Republic of Uzbekistan establishes administrative penalties for violating almost all the rules provided by these rules of the road. In our view, the rules of the road should be adopted not only by the Cabinet of Ministers of the Republic of Uzbekistan, but also in the form of laws adopted by the parliament.

\footnotetext{
${ }^{5}$ Constitution of Brazil. www.twirpx.com

${ }^{6}$ Constitution of the PRC. chinalawinfo.ru 9
} 


\section{THE AMERICAN JOURNAL OF SOCIAL SCIENCE AND EDUCATION INNOVATIONS}

\section{[Volume-II Issue-III][Pages = X-XVIII][Mar 2020]}

\section{Website: http://usajournalshub.com/index.php/tajssei ISSN (e): 2689-100X}

Impact Factor 2019 (5.366)

In order to clarify this issue it is necessary to clearly define the list of social relations regulated by the Supreme Assembly of the Republic of Uzbekistan through the law. Let us look at the experience of the constitutions of foreign countries in this regard. According to Article 74 of the Basic Law for the Federal Republic of Germany, civil law, criminal law and criminal executive law, judicial system, legal proceedings, advocacy, notary and legal advice are provided; civil status documents; the right of association and assembly; the right of foreigners to stay and stay in the country; arms and explosives legislation; refugee work and accommodation; state social security; military damage and compensation; provision of war invalids, relatives of the dead, and protection of former prisoners of war; lost soldiers, graves of other victims of war; economic law (mining, industry, energy industry, crafts, handicraft industry, trade, banking and stock exchange, private insurance); development and use of nuclear energy for peaceful purposes, protection against the dangers of nuclear energy release, burial of radioactive materials; labor law, including employment, mediation in employment and employment, as well as social insurance with unemployment insurance; regulating educational subsidies and facilitating research; non-railway tracks; waste disposal, air pollution and noise control; the responsibility of the state; areas such as artificial reproduction, artificial reproduction and related studies, as well as the regulation of human organ and tissue transplants, and the approval of such laws by the upper house of Parliament, the Bundesrat. ${ }^{7}$

Article 81 of the Constitution of Spain states that laws related to the development of fundamental rights and freedoms, laws that are the basis of the electoral system, and other laws envisaged in the Constitution are organic laws. The purpose and scope of the legal powers conferred by Article 82 of the Constitution, as well as the principles and criteria for their implementation, are determined by the basic laws ${ }^{8}$.

According to Article 94 of the Constitution of the Republic of Azerbaijan, the Parliament of the Republic of Azerbaijan shall enjoy the fundamental rights and freedoms of individuals and citizens, as well as state guarantees of these rights and freedoms; Elections of the President of the Republic of Azerbaijan; Elections of the National Assembly of the Republic of Azerbaijan and the status of deputies of the National Assembly of the Republic of Azerbaijan; referendum; the structure of the judiciary and the status of judges, the prosecutor's office, the prosecution and the notary; legal proceedings, execution of court decisions; Municipal elections and the status of municipalities; emergency mode; military regime; state awards; status of natural and legal persons; objects of civil law; civil-law agreements, representation and inheritance issues; identify crimes and other offenses; establishing responsibility for their occurrence; defense and military service; public service; security bases; territorial structure; general rules concerning the regime of state borders and other issues ${ }^{9}$.

The Cabinet of Ministers of the Republic of Uzbekistan takes an active part in the legislative process, with the following main forms of direct participation in law-making:

- Participation in the process of drafting laws proposed by the President of the Republic of Uzbekistan at meetings of the chambers or other official events;

\footnotetext{
7 Basic Law (Constitution) of the Federal Republic of Germany. www.pproektua.org

${ }^{8}$ Constitution of Spain.www.congreso.es

${ }^{9}$ Constitution of the Republic of Azerbaijan. www.meclis.gov.az
} 


\title{
THE AMERICAN JOURNAL OF SOCIAL SCIENCE AND EDUCATION INNOVATIONS
}

\section{[Volume-II Issue-III][Pages = X-XVIII][Mar 2020]}

\section{Website: http://usajournalshub.com/index.php/tajssei ISSN (e): 2689-100X}

\author{
Impact Factor 2019 (5.366) Impact Factor For Current Year (5.525)
}

- Participation in lawmaking process on execution of tasks set by normative legal acts adopted by the President of the Republic of Uzbekistan;

- Implementation of the draft laws of the Government of the Republic of Uzbekistan for the next year approved by the Cabinet of Ministers;

- Development of draft laws proposed by the Chambers of Parliament.

In addition, the role of the Cabinet in the process of drafting a new law regulating a particular area or regulating a particular field is virtually negligible, given the tasks envisaged by the legislative decisions adopted on a particular issue..

It should be noted that due to the lack of effective systematic analysis of law enforcement by the Cabinet of Ministers in the legal acts issued by the President of the Republic of Uzbekistan or monitoring the activities of the Cabinet of Ministers on the development of draft laws, specified by the Cabinet of Ministers, for the next year many draft laws have not been developed in this regard.

It is noteworthy that although some of the issues related to lawmaking have been repeatedly proposed and demanded by the head of state, it is the executive branch that has not yet implemented such laws. This, in turn, creates legal gaps in the legal regulation of a particular area and conflicts between the rules of the law.

For example, the task of developing and adopting the Law of the Republic of Uzbekistan "On Internal Affairs Bodies", published in the media on September 16, 2016 and entered into force on March 18, 2017, has been repeatedly reflected in the relevant legislation and the system of Executive authorities ${ }^{10}$. Responsible state authorities, the content of the law is clearly provided for. In particular, the draft law "On measures for liberalization and deepening of reforms in political, economic and spiritual spheres of society, the implementation of programs to ensure national security" was assigned to the Ministries of Internal Affairs, Justice, Higher Education and Finance in the Decree of the President of the Republic of Uzbekistan dated June 2, 2000 № PD-2612. The first quarter of 2001 was defined as the deadline for developing this bill11. In addition, the task of developing a draft law "On Internal Affairs Bodies" is envisaged in the Decree of the President of the Republic of Uzbekistan dated March 10, 2005 № PD-24 "Concept on realization of priorities in the sphere of further liberalization and reforming of judicial and legal system"12. It is defined by the executive bodies as well as the judicial authorities as the state bodies responsible for the development of this law.

\footnotetext{
${ }^{10}$ Law of the Republic of Uzbekistan "On Internal Affairs Bodies” Law of the Republic of Uzbekistan No. DRU-407 "On the introduction of amendments and supplements to certain legislative acts of the Republic of Uzbekistan"

${ }^{11}$ Decree of the President of the Republic of Uzbekistan dated 02.06.2000 No. PD-2612 "On measures to implement programs to liberalize and deepen reforms in the political, economic and spiritual spheres of society, to ensure the country's security". www.lex.uz

${ }^{12}$ Decree of the President of the Republic of Uzbekistan dated 10.03.2005 No. PD-24 "On the Program for Realizing the Goals and Tasks of Democratization and Renewal of the Society, Reforming and Modernization of the Country". "Collection of Legislation of the Republic of Uzbekistan", 2005, No. 10-11, Art. 71
} 


\title{
[Volume-II Issue-III][Pages = X-XVIII][Mar 2020]
}

\author{
Website: http://usajournalshub.com/index.php/tajssei ISSN (e): 2689-100X
}

Impact Factor 2019 (5.366)

Impact Factor For Current Year (5.525)

President of the Republic of Uzbekistan Shavkat Mirziyoyev made a special speech at the ceremony of celebration of the 24th anniversary of the adoption of the Constitution of the Republic of Uzbekistan, entitled "Ensuring the rule of law and human interests - the guarantee of the development of the country and the welfare of the people". The President of the Republic of Uzbekistan Shavkat Mirziyoyev made a special speech at the ceremony of celebration of the 24th anniversary of the adoption of the Constitution of the Republic of Uzbekistan, entitled "Ensuring the rule of law and human interests - the guarantee of the development of the country and the welfare of the people": "At the same time, an effective system will be created to reform the Institute of Public Service, radically improve the material and social support of civil servants, their professional training, attract new-thinking, responsible, initiative, patriotic personnel to this sphere. All these issues are reflected in the recently developed law "On Public Service"."13

Despite the fact that the need for adoption has been underlined for more than 20 years, the fact that the Law "On Public Service" has not yet been developed shows that the task of drafting laws to the Cabinet and the relevant legislation has not been implemented.

In our opinion, one of the main reasons for this situation is the lack of proper systematic and regular control over the implementation of the legislation, which is assigned to the Cabinet of Ministers by the President and the Legislative Chamber of the Republic of Uzbekistan.

Based on the foregoing, taking into account the experience of the constitutions of foreign countries, it is proposed to further strengthen the independence of the executive branch and increase its responsibility, increase the role of the institution of parliamentary control over the implementation of adopted laws, and clearly define the areas of stable public relations regulated by the parliament in the Constitution of the Republic of Uzbekistan.

As we have seen, determining which areas of legislation are regulated by Parliament can help ensure that the government can act independently by passing legislation in other areas, thereby increasing its responsibility for the legislation it adopts.

In addition, the adoption of laws governing specific areas by parliament allow for direct parliamentary oversight of the implementation of laws in these areas.

Parliament has the ability to adopt relevant laws and have a significant impact on the activities of the executive branch. Russian scientist professor B.V. Rossinsky noted that the system of executive power by its nature manifests itself as an integral system of state power, ${ }^{14}$ and in the performance of all the functions inherent in state power, the system of executive power should be established by the parliament in laws ${ }^{15}$. The purpose of this is to ensure that the executive branch adopts statutory acts; control, preventing monopolization of power by consolidating organizational and economic functions in the hands of one body.

\footnotetext{
13 The rule of law and the protection of human interests are the key to the country's development and prosperity. Speech by President-elect of the Republic of Uzbekistan Shavkat Mirziyoyev on the occasion of the 24th anniversary of the Constitution of the Republic of Uzbekistan. www.uza.uz

${ }^{14}$ Note 6: B.V. Rossinsky divides these functions into three groups: adoption of regulatory acts; control (licensing, registration, etc.); organizational and economic functions (management of state property and provision of public services).

${ }^{15}$ Executive power in Russia. History and Present, Problems and Prospects of Development - New Legal Culture, 2004 -P. $78-81$.
} 


\section{THE AMERICAN JOURNAL OF SOCIAL SCIENCE AND EDUCATION INNOVATIONS}

\section{[Volume-II Issue-III][Pages = X-XVIII][Mar 2020]}

\section{Website: http://usajournalshub.com/index.php/tajssei ISSN (e): 2689-100X}

Impact Factor 2019 (5.366)

M. Akhmedshaeva, a legal scholar who has conducted a special study of executive power in the system of state power, analyzes government norms in the constitutions of national and foreign states, concludes that "in the modern system of statehood, it is observed that government functions as an effective institution, especially in the present age of globalism, information and high technology and, accordingly, political, economic and social processes put many complex tasks and problems before the state, undoubtedly, the role and importance of government in solving them rapidly is high." 16

In turn, the effective functioning of the government, which is a branch of executive power in the system of state power, should be carried out in such a way that its independence and responsibility are increased with the strict observance of the principle of reciprocity between the branches of legislative and judicial power of the state power and the balance of interests.

The priority direction of further democratization of the executive power system, increasing the responsibility of government for the implementation of tasks in the field of socio-economic, humanitarian development of the country, ensuring reliable protection of human rights and legitimate interests is one of the pressing issues of responsibility and independence of the executive in the Republic of Uzbekistan.

The implementation of this priority area requires a number of important reforms in a number of areas of government, in particular, to improve the system of executive bodies. It is desirable that such reforms be implemented directly in the following areas:

To create an effective legal framework for the implementation of constitutional norms provided for the independence and responsibility of the Cabinet of Ministers of the Republic of Uzbekistan for fulfilling the tasks facing the government. The government needs to establish and ensure the effective exercise of its powers to formulate and implement policies in other sectors of the economy and the social sphere, which are clearly defined by economic, social, financial, monetary and credit policies, programs for the development of healthcare, education, culture, science and the latest amendments to the article 98 of the Constitution.

It is important to gradually ensure that printouts of a market economy are introduced into the management process. This means not only a reduction in bureaucracy, but also the transformation of administrative structures into entrepreneurial organizations capable of exerting an active influence on the development of society by virtue of the nature of management methods. At the same time, it is important to help increase the coordinating role of the government, the independence and responsibility of ministries, departments and departments for the fulfillment of their tasks.

Organization of highly qualified personnel potential of government. The Bund as one of the important requirements is the organization of an effective training system for civil servants-managers with modern and independent thinking, democratic reforms, and modern management methods in the context of the formation of a strong civil society that does not have civilized managerial stereotypes. One of the important requirements for a leader is his experience, knowledge and self-confidence.

\footnotetext{
${ }^{16}$ Akhmedshaeva M. A. Executive power in the system of state authority. 12.00.01 - Theory and history of state and law; thesis for the degree of Doctor of Jurisprudence in History of political and legal doctrines. - Tashkent, 2010. - 208 p.
} 


\section{THE AMERICAN JOURNAL OF SOCIAL SCIENCE AND EDUCATION INNOVATIONS}

\section{[Volume-II Issue-III][Pages = X-XVIII][Mar 2020]}

\section{Website: http://usajournalshub.com/index.php/tajssei ISSN (e): 2689-100X}

Impact Factor 2019 (5.366)

An important role in the process of political modernization is played by the widespread use of modern information and communication technologies in the public administration system. In this regard, the system "e-government" is aimed at further improving full-fledged work, providing high-quality public services to citizens and enterprises, introducing electronic forms of interaction with citizens and business entities of state and regulatory bodies. It is important to create a national system of departmental and interdepartmental unified information systems. The measures taken in this area should ensure a significant reduction in the costs of solving various household issues of citizens and state bodies, as well as reducing bureaucratic processes. Speaking about this, as the doctor of legal sciences, M. Akhmedshaeva, rightly admitted, special requirements are placed on the government, including the organization of its activities and the improvement of interaction with the population, as well as ensuring the transfer of decisions to citizens based on modern features. These requirements are related to making the government's work more accessible to the public through the use of science and technology. To this end, it is necessary to expand the possibilities of modern media and the use of international Internet communication systems. This approach also helps to ensure the transparency of the executive branch. ${ }^{17}$

The introduction of objects and systems for assessing and measuring the effectiveness of public authorities, executive bodies of state power is an important task. Management should restore its activities based on the principle of "more freedom, more initiative and responsibility at the same time". It is necessary to introduce a phased system of "preventive management", which is a criterion for assessing state bodies adopted in foreign countries, not only their ability to solve problems arising in the process of vital activity of the population, providing industries, but also the ability to anticipate and solve such problems in advance.

The executive branch, in an effort to increase its independence and responsibility, calls for the development of a draft law "on standards for the provision of state legal services" in addressing the above and other tasks, and the introduction of relevant amendments and additions to the laws "on local state power".

\section{References}

1. Address by the President of the Republic of Uzbekistan Shavkat Mirziyoev to the Supreme Assembly // http://press-service.uz/uz/lists/view/1371

2. Akhmedshaeva M. A. Executive power in the system of state authority. 12.00.01 Theory and history of state and law; thesis for the degree of Doctor of Jurisprudence in History of political and legal doctrines. - Tashkent, 2010. - 208 p.

\footnotetext{
${ }^{17}$ Akhmedshaeva M. A. Executive power in the system of state authority. 12.00.01 - Theory and history of state and law; thesis for the degree of Doctor of Jurisprudence in History of political and legal doctrines. - Tashkent, 2010. - 208 p.
} 


\title{
THE AMERICAN JOURNAL OF SOCIAL SCIENCE AND EDUCATION INNOVATIONS
}

\section{[Volume-II Issue-III][Pages = X-XVIII][Mar 2020]}

\author{
Website: http://usajournalshub.com/index.php/tajssei ISSN (e): 2689-100X
}

Impact Factor 2019 (5.366) Impact Factor For Current Year (5.525)

3. Akhmedshaeva M. A. Executive power in the system of state authority. 12.00.01 Theory and history of state and law; thesis for the degree of Doctor of Jurisprudence in History of political and legal doctrines. - Tashkent, 2010. - $208 \mathrm{p}$.

4. Basic Law (Constitution) of the Federal Republic of Germany. www.pproektua.org

5. Chirkin V.E. Fundamentals of comparative state science. M.: Lawyer, 2001 .- P.85.

6. Constitution of Brazil. www.twirpx.com

7. Constitution of Spain.www.congreso.es

8. Constitution of the PRC. chinalawinfo.ru 9

9. Constitution of the Republic of Azerbaijan. www.meclis.gov.az

10. Decree of the President of the Republic of Uzbekistan dated 02.06.2000 No. PD2612 "On measures to implement programs to liberalize and deepen reforms in the political, economic and spiritual spheres of society, to ensure the country's security". www.lex.uz

11. Decree of the President of the Republic of Uzbekistan dated 10.03.2005 No. PD-24 "On the Program for Realizing the Goals and Tasks of Democratization and Renewal of the Society, Reforming and Modernization of the Country". "Collection of Legislation of the Republic of Uzbekistan", 2005, No. 10-11, Art. 71

12. Executive power in Russia. History and Present, Problems and Prospects of Development - New Legal Culture, 2004 -P. 78-81.

13. Hamaneva N.Yu. Executive power in Russia. History and modernity, problems and development prospects - New Legal Culture, 2004 - P. 4.

14. Law of the Republic of Uzbekistan "On Internal Affairs Bodies" Law of the Republic of Uzbekistan No. DRU-407 "On the introduction of amendments and supplements to certain legislative acts of the Republic of Uzbekistan"

15. Note 6: B.V. Rossinsky divides these functions into three groups: adoption of regulatory acts; control (licensing, registration, etc.); organizational and economic functions (management of state property and provision of public services).

16. Starilov Yu.N. General Administrative Law Course. T. 1. M .: Norma, 2002.-P. 67.

17. The rule of law and the protection of human interests are the key to the country's development and prosperity. Speech by President-elect of the Republic of Uzbekistan Shavkat Mirziyoyev on the occasion of the 24th anniversary of the Constitution of the Republic of Uzbekistan. www.uza.uz 